\title{
MISCELLANEOUS REMARKS ON BALTO-SLAVIC ACCENTUATION
}

\author{
FREDERIK KORTLANDT
}

The highly successful conference on Balto-Slavic accentology organized by Mate Kapović and Ranko Matasović has given much food for thought. It has clarified the extent of fundamental disagreements as well as established areas of common interest where the evidence seems to be ambiguous. In the following I shall comment upon some of the papers presented at the conference which are directly relevant to my own research.

Miguel Carrasquer Vidal claims that PIE barytone thematic verbs adopted mobile stress in Balto-Slavic whereas PIE derived thematic verbs preserved stress on the thematic vowel. This hypothesis does not explain the actual distribution of the accent types (cf. Stang 1957: 155-167 and 1966: 474-482). My conjecture is that as a rule, originally athematic verbal paradigms have mobile stress while original thematic verbal paradigms (including the thematic aorist, which appears to continue an earlier imperfect) have fixed stress on the stem, not on the thematic vowel, unless they adopted mobile stress at a recent stage. This is a topic which requires further investigation. I shall not go into other aspects of Carrasquer's interesting paper.

Rick Derksen reconsiders Winter's law against the background of Dybo's recent treatment (2002). As I have discussed Winter's law in detail elsewhere (1988), I can be brief here (cf. also Derksen 2002). The only point I have to highlight again is that Winter's law was blocked in the clusters $*_{-} n d n-<*_{-} d n$ - and *-ngn- <*-gn-, e.g. in the Slavic words for 'water' and 'fire', cf. especially SCr. ségnuti beside sëzati 'reach', Czech sáhnouti beside sahati 'touch', because the glottalization had in this position been lost as a result of neutralization in ProtoIndo-European already, as had voicelessness, e.g. in Latin pandō 'spread', pingō 'paint', mungō 'slime' beside Gr. pitnēmi, Skt. piṃśáti, muñcáti with restoration of the original stop (cf. Thurneysen 1883). Incidentally, it is quite clear from Slovene jàz 'I' that Winter's law operated in stressed syllables as it did in unstressed syllables.

Vladimir Dybo identifies two accent types, with fixed and mobile stress, for Balto-Slavic thematic presents of verbs with a root-final resonant or vowel. In accordance with the conjecture put forward above, I think that presents with mobile stress represent original athematic paradigms whereas presents with fixed stress continue earlier thematic formations. This view is supported by the apophonic al- 
ternations between žře-, purre-, lije-, rǔve- and žere-, pere-, lěje-, ruje-, also koveand kuje-, where $* k \breve{u} v$ - was evidently eliminated in order to remove the homonymy with kǔvati, kyje- 'shake one's head' (cf. Vaillant 1966: 284), and smějese (cf. Vaillant 1966: 291), all of which belong to the mobile accent pattern. A similar prehistoric alternation may be assumed for p̌ne- and vije-. The present orje- 'plough' evidently adopted mobile stress at an early stage (cf. Vaillant 1966: 513). The present žive- 'live' apparently took its mobile stress from the root aorist in Balto-Slavic times already because this accent pattern is confirmed by the Prussian evidence (cf. Kortlandt 1987: 106). In the case of bljuje- 'vomit', original accentual mobility is supported by the apophonic alternation in Greek phléo, phlúo 'overflow'. The presents blěje-, děje- 'put', daje-, maje-, staje- retain the mobile stress of the root aorist from which they were derived. On the other hand, no traces of apophonic alternation are found in the type with fixed stress, except for kryje'cover', where the full grade found in East Baltic was eliminated, as it was in Prussian. All of these instances are original je-presents, where root stress is regular, including not only žrr $(j) e$ - and $t \check{\imath} r(j) e$ - (cf. Vaillant 1966: 190) but also mine'crumple', which was apparently disambiguated from mini- 'think'. The presents spěje- and děje- 'do' are evidently denominatives of verbal root nouns, cf. Latin spēs, - dès.

Dybo claims that the same distribution of verbal paradigms is found in Germanic, where shortening of (pretonic) long vowels and Verschärfung correspond to Balto-Slavic accentual mobility while preservation of long vowels and no Verschärfung correspond to Balto-Slavic fixed stress on the root. Here again, the latter category are $j e$-presents except *spiwa- beside *sp(j) $\bar{u} j a$ - 'spit'. The verbs with

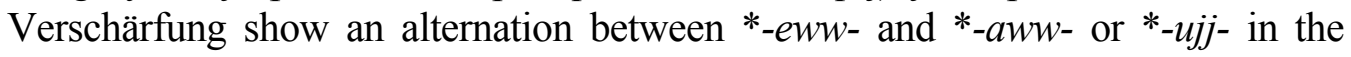
root. The problem clearly needs further investigation.

Georg Holzer has presented a partial chronological ordering of 35 Slavic developments from the earliest dialectal differentiation up to the neo-Štokavian retraction of the stress. Since his treatment requires a detailed examination of the evidence, I shall discuss it on another occasion.

Mate Kapović discusses the accent type of Slavic *vòl'a. He presents lists of jastem nouns with fixed stress and acute (a) or neo-acute (b) tone on the root but finds few instances of $j a$-stem nouns with mobile (c) or desinential (b) stress. In my view, the latter are relics of original Balto-Slavic $\bar{e}$ - and $\bar{\imath} / j \bar{a}$-stems. For $d u \check{s} a$ (c) 'soul' I assume an $\bar{\imath} / j \bar{a}$-stem (cf. Kortlandt 1997b: 158 and 2001: 61), for zemlja $(\mathrm{b}, \mathrm{c})$ 'earth', Lith. žẽmé (2) an $\bar{e}$-stem continuing the Indo-European root noun, for *medja (b, c) 'border', Lith. mẽde (2) 'forest' an $\bar{\imath} / j \bar{a}$-stem beside the jo-stem of Lith. mẽdis (2) 'tree', Latin medius 'middle', for želja (c) 'wish' and lǔža (b) 'lie', Old High German lugi original $\bar{\imath} / j \bar{e}$-stems because these are deverbal abstracts (cf. Kortlandt 1997b: 161f.), for *gospodja (c) 'lady' an $\bar{\imath} / j \bar{a}$-stem, as in Lith. pati (4) 'wife', gen. pačiõs, for zorja, zarja (c) 'dawn', OPr. sari 'Glut' an $\bar{\imath} / j \bar{e}$ - or $\bar{\imath} / j \bar{a}$-stem replacing an earlier verbal root noun, and for *rŭdja (c) 'rust' and *světja (b) 'can- 
dle' original $\bar{\imath} / j \bar{a}$-stems, though the latter may actually have adopted the flexion of Lith. žvãke (2) 'candle' at an earlier stage. Other $\bar{l} / j \bar{e}$-stems apparently joined the $j \bar{a}$-stems at an early stage already, e.g. volja 'will', Lith. valià (2).

My own contribution to the conference deals with the Serbo-Croatian evidence for Indo-European long and short vowels and discusses an unpublished paper by Kapović which the author had kindly put at my disposal. These two articles will be published together with Holzer's contribution in a forthcoming volume of the Wiener Slavistisches Jahrbuch.

Keith Langston has shown that the Čakavian evidence for a fourth Slavic accent pattern (d) distinct from (b) and (c) but resembling both of these in the combination of a long falling tone on the root with desinential stress in the oblique case forms is inconclusive. This type can easily have arisen by the loss of a rising tone and analogical lengthening in monosyllables of accent pattern (b) and by the extension of desinential stress and the reduction of accentual mobility in accent pattern (c). The spread of final stress in the mobile accent paradigm probably started from the gen.sg. form of the $u$-stems, which had final stress, as in Lith. sünaũs (cf. Stang 1957: 88 on the $i$-stems and Steinhauer 1973: 90 on an accent pattern in Senj which is not mentioned by Moguš). Nevertheless, it is still possible that some nouns such as $z \hat{u} b$ 'tooth' escaped the early generalization of mobile stress in the masculine $o$-stems and thereby ended up in accent pattern (b) instead of (c) in a part of the Slavic territory. The crucial evidence, to my mind, comes from the accentuation of deverbal nouns such as razdél, gen. razdèlà (or razdêl, razdēlä) 'section', which does not seem to be found outside the Čakavian area. This type can hardly be explained otherwise than by the hypothesis that it had escaped the early generalization of mobile stress before Dybo's law (cf. Kortlandt 1975: 28 and 1979).

Ranko Matasović discusses early Latin and Romance loanwords which belong to accent paradigms (a), mostly $a$-stems, and (b), always $o$-stems, in South Slavic. He argues that the latter entered the language either before Dybo's law or after the retraction of the stress from final jers. In my view, the former hypothesis is correct and the latter development is irrelevant because Dybo's law did not shift the stress to final jers (cf. Kortlandt 1975: 13-19 for details), so that the nom.acc.sg. form of the $o$-stems was always stem-stressed.

Thomas Olander rejects the traditional view going back to Saussure and Pedersen that accentual mobility in nominal paradigms originated in the consonant stems and spread to vocalic stems in Balto-Slavic. Instead, he thinks that the stress was retracted from a short vowel before a final consonant or an intervocalic hiatus, e.g. nom.sg. *-ós, abl.sg. *-óat, but not before a final laryngeal or an intervocalic consonant, e.g. nom.sg. *-áH, dat.pl. *-óbhos. This not very logical hypothesis is at variance with the following case forms (Lithuanian unmarked): 
(1) nom.sg. gaidỹs 'rooster' < *-iòs, also geràs-is '(the) good', širdìs 'heart', sünùs 'son',

(2) gen.sg. galvõs 'head' < *-àHos (Olander *-áHs, which does not explain the circumflex), širdiẽs, sūnaũs, Russ. desjatí ‘ten’ (cf. Stang 1957: 88),

(3) inst.sg. lángu 'window' < *-òH, gálva, širdimi, sūnumì, Russ. désjat’ju (cf. Stang 1957: 88),

(4) loc.sg. namiẽ 'at home' < *-òi, galvojè < *-àHi-, Russ. golové,

(5) nom.acc.du. lángu $<*_{-} o \dot{H}$ (Olander *-óe, which does not explain the acute), šìrdi, sǘnu, Slovene možâ, duhộva (cf. Stang 1957: 73),

(6) nom.pl. langaĩ, širdys <*-éies, sǘnūs, Slovene duhộvi,

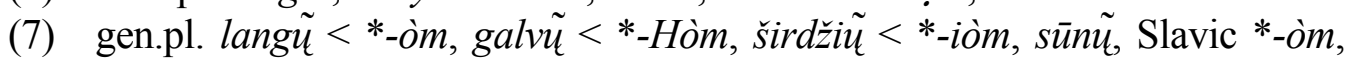
*-eiòm, *-euòm (cf. Kortlandt 1978; Olander's *-óom, *-áHom, *-éiom, *-éuom do not explain the final stress),

(8) dat.pl. Czech -ům <*-óm <*-omùs, Russ. détjam <*-imùs, Slovene možệm $<* m o \ddot{z} e m<*$-umùs, with the same retraction of the stress across the pretonic jer as in Sln. dánes 'today' <*dini-si (Olander has *-bhos for *-mus),

(9) inst.pl. langaĩs <*-òois (Olander *-óeis), galvomìs, širdimìs, sūnumis, Czech -ý (cf. Stang 1957: 38), Russ. det'mí, Sln. možmí,

(10) loc.pl. languosè, galvosè, avisù 'sheep', Sln. možẹ́h < *-oisù, Russ. détjax < *-isù. I conclude that Olander's theory is quite inadequate.

Jens Elmegård Rasmussen thinks that monosyllables are always "circumflex" in Balto-Slavic. Unfortunately, he does not distinguish between a Baltic circumflex, which is the absence of an acute tone (i.e. of glottalization), and a Slavic circumflex, which is a falling tone that developed at a more recent stage in paradigms with mobile stress independently of the original presence or absence of an "acute" (i.e. of a glottal stop). Rasmussen claims that the shortening of an acute $y$ and $\bar{u}$ in Lith. monosyllabic future forms, e.g. gis 'will heal', is analogical after polysyllabic forms such as rašìs beside rašỹ 'will write' in spite of the facts that it is a receding phenomenon, that forms like rašis are limited to southern and eastern Aukštaitian dialects, and that there is no model for the verbs in - $\bar{u} t i$ (cf. Kortlandt 2002). He arbitrarily posits a Balto-Slavic $i$-stem for Lith. žverìs 'beast' and Slavic *mūs- (a) 'mouse' but a consonant stem for *rēk- (c) 'speech' though the Lith. word is still attested as a consonant stem and the tones of the Slavic words reflect fixed stress and accentual mobility, not original tone or stem formation. Personal and demonstrative pronouns were originally root-stressed in Balto-Slavic, so that the falling tone of Slovene $t \hat{\imath}, m \hat{\imath}, v \hat{\imath}, t \hat{a}, t \hat{o}, t \hat{\imath}, t e ̣ ̂$ cannot be original. It reflects the recent lengthening of an earlier short vowel, which is still preserved in jàz 'I' (similarly in the neighboring Čakavian dialects). This is clear from the fact that the personal pronouns have neo-acute tone in Posavian and in most Čakavian dialects of Croatia (cf. Jurišić 1966: 84 and Kortlandt 1997a: 29; note that the standard language has lost the distinction between neo-acute and circumflex). Czech and Slovak have 
preserved the original short reflex of the acute in $t y, m y, v y$ while the latter language has faithfully preserved the neo-acute in the demonstrative pronoun. In Baltic, the original acute is well preserved in Prussian $t o \bar{u}, i o \bar{u} s$, Latvian $j \tilde{u} s$, but not in

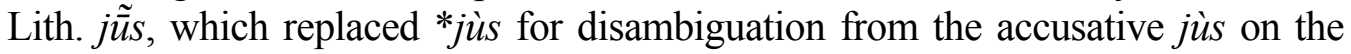
analogy of mẽs, mùs. The acute tone of Latvian nom.pl. tie (which was lost in standard Lithuanian but has been preserved in the dialects) reflects the original neuter ending (cf. Kortlandt 1993). The falling tone in the Slavic root aorist is a consequence of its mobile accent pattern. It is spreading in Serbo-Croatian at the expense of the type with fixed stress on an acute root vowel, which evidently continues a sigmatic aorist of vocalic roots with a je-present (see above). The latter morphological type has an en-participle while the former has a $t$-participle.

Thus, we must be grateful to Kapović and Matasović for bringing together a number of scholars with different backgrounds in the complex field of BaltoSlavic accentology. There are important problems which remain to be solved, especially regarding the Indo-European origins of Balto-Slavic verbal paradigms as discussed by Carrasquer and Dybo. Another point of special interest is the chronology of accentual developments, which has a major impact on the topics discussed by Holzer, Kapović, Langston, Matasović, Olander and Rasmussen. The conference has given a powerful boost to the scholarly attention required for further progress in our field of study.

\section{REFERENCES}

Derksen, Rick

2002 On the reception of Winter's law. Baltistica 37/1, 5-13.

Dybo, Vladimir A.

2002 Balto-Slavic accentology and Winter's law. Studia Linguarum 3/2 (Gs. Korolev), 295-515.

Jurišić, Blaž

1966 Rječnik govora otoka Vrgade, I dio (Zagreb: JAZU).

Kortlandt, Frederik

1975 Slavic accentuation: A study in relative chronology (Lisse: Peter de Ridder), also available at www.kortlandt.nl.

1978 On the history of the genitive plural in Slavic, Baltic, Germanic, and IndoEuropean. Lingua 45, 281-300.

1979 Sur l'accentuation des noms postverbaux en slave. Dutch contributions to the eighth international congress of Slavists, Zagreb (Lisse: Peter de Ridder), 325328.

1987 The formation of the Old Prussian present tense. Baltistica 23/2, 104-111.

1988 Remarks on Winter's law. Studies in Slavic and General Linguistics 11 (Dutch contributions to the tenth international congress of Slavists, Sofia), 387-396.

1993 Tokie šalti rytai. Baltistica 28/1, 45-48.

1997a PIE. lengthened grade in Balto-Slavic. Festschrift for Eric P. Hamp, vol. II, 2631. 
1997b Baltic $\bar{e}$ - and $\bar{\imath} / j \bar{a}$-stems. Baltistica 32/2, 157-163.

2001 Diphthongization and monophthongization in Old Prussian. Res Balticae 7, 5765.

2002 Shortening and metatony in the Lithuanian future. Baltistica 37/1, 15-16.

Steinhauer, Hein

1973

Čakavian studies (The Hague: Mouton).

Stang, Christian S.

1957 Slavonic accentuation (Oslo: Universitetsforlaget).

1966 Vergleichende Grammatik der baltischen Sprachen (Oslo: Universitetsforlaget).

Thurneysen, Rudolf

1883 Urspr. dn, tn, cn im Lateinischen. Zeitschrift für vergleichende Sprachforschung 26, 301-314.

Vaillant, André

1966

Grammaire comparée des langues slaves, tome III: Le verbe (Paris: Klincksieck). 